\title{
INVESTIGATION OF ROCK AGGREGATE QUALITY IMPROVEMENT THROUGH CHANGES IN CRUSHING CIRCUIT: A CASE STUDY ON VERTICAL SHAFT IMPACT CRUSHER
}

\author{
${ }^{1}$ Ekin KÖKEN ${ }^{(i)}$, ${ }^{2}$ Kerem ÇİMŞiR \\ ${ }^{1}$ Abdullah Gul University, Engineering Faculty, Nanotechnology Engineering Department, Kocasinan, 38100, \\ Kayseri, TURKEY \\ ${ }^{2}$ DKT Construction, Industry and Trade Inc., Yeşilce st. 11/6, Kağıthane, 34418, Istanbul, TURKEY \\ 12ekin.koken@agu.edu.tr, ${ }^{2}$ kerem.cimsir@dkt.com.tr
}

(Geliş/Received: 31.01.2021; Kabul/Accepted in Revised Form: 02.11.2021)

\begin{abstract}
The present study investigates the effects of rock crushing circuits on aggregate quality. For this purpose, a crushing - screening plant located in Vize (Kirklareli, Turkey) was considered. Based on the current operating conditions, the crushing - screening plant was modeled. The simulations revealed quantitative data on the production yield, efficiency of crushers, size reduction ratio. Concerning cone and vertical shaft impact crushers, rock aggregate quality was investigated for products with a particle size range of $33-63 \mathrm{~mm}$. As a result of full-scale crushing tests, it was determined that the quality of rock aggregates is affected by the crushing circuit. Thanks to the several changes in crushing circuit, the Los Angeles abrasion value and flakiness index of the investigated rock aggregates were improved by $32 \%$ and $35 \%$, respectively. The key points and details on the aggregate quality improvement processes were given in this study.
\end{abstract}

Key Words: Crushing - screening plant, Crushed stone, Aggregate quality, Cone crusher, Vertical shaft impact crusher

\section{Agrega Kalitesi İyileştirmenin Kırma Döngüsü Değişimi İle Araştırılması: Dik Milli Kırıcı İçin Örnek Bir Çalışma}

ÖZ: Bu çalışma kaya kırma döngüsünün agrega kalitesi üzerinde olan etkilerini araştırmaktadır. Bu amaçla, Vize'de (Kırklareli, Türkiye) bulunan bir kırma - eleme tesisi dikkate alınmıştır. Mevcut çalışma koşulları dikkate alınarak, kırma - eleme tesisinin bilgisayar ortamında simülasyonu yapılmıştır. Simülasyonlar üretim miktarı, kırıcıların verimliliği ve boyut küçültme oranı gibi niceliksel verileri içermektedir. Konik ve dik milli kırıcılar dikkate alınarak, kaya agrega kalitesi $33-63 \mathrm{~mm}$ boyut grubundaki agregalar için araştırılmıştır. Büyük ölçekte gerçekleştirilen parçalanma deneylerinde, kaya agrega kalitesinin kırma döngüsünden etkilendiği belirlenmiştir. Kırma döngüsünde yapılan bazı değişimler ile, araştırılan agregaların Los Angeles aşınma değeri ve yassılık indeksi sırasıyla \%32 ve \%35 oranlarında iyileştirilmiştir. Bu çalışmada agrega kalitesi iyileştirme süreçlerine ilişkin ana hatlar ve detaylar verilmiştir.

Anahtar Kelimeler: Kırma - eleme tesisi, Kırmataş, Agrega kalitesi, Konik kırıcı, Dik milli kırıcı

\section{INTRODUCTION}

Increasing demand for crushed stones throughout the world impels aggregate manufacturers to improve the rock aggregate production processes. In any case, these attempts aim to decrease production costs and enhance rock aggregate quality. As a matter of fact, rock aggregate quality encompasses strength, size, and shape considerations (Metso 2018). Therefore, they constitute a strong basis on the 
technical and economic value of rock aggregates used for building and construction purposes. Because the natural resources should be utilized efficiently, apart from inherent drawbacks, rock aggregate quality can conceptually be enhanced by removing weathered, highly fractured, or undesirable particles from the final product. In this context, selective drilling - blasting operations can play a crucial role in removing/minimizing weathered particles from the final product (Köken et al., 2020). In addition to this, it can also be possible to consider various crushing and screening operations for obtaining relatively higher quality rock aggregates (Ulsen et al., 2019; Davoodi et al., 2019).

Rock breakage or comminution is mainly associated with rock-crusher interactions, crushing energy consumption, and product-based evaluations, regarding modern rock aggregate science and technology. In this manner, rock crushing operations may be divided into three main phases: primary, secondary, and tertiary crushing operations, each of which has several specifications covering belt conveying systems, screens, and types of crushers (Leiva et al., 2018).

Of the variability in crushing machines, jaw crushers known for their ability to crush huge rock blocks are mainly used in the primary crushing stages. Thus, they are ideal for daily operations with a relatively low-cost crushing. Cone crushers break down materials by compressing them between concave and convex-shaped surfaces. Unlike other crusher types, cone crushers have a more stable structure that enables higher capacity. Thanks to this advantage, they are highly utilized, particularly in secondary and tertiary crushing operations. The vertical shaft impact (VSI) and horizontal shaft impact (HSI) crushers use impact forces to crush materials in the crushing chamber. More profoundly, VSI type crushers can handle hard and abrasive materials, which can be declared its main advantage over HSI-type crushers.

Generally, unsuitable crushers and poor-quality crushing equipment result in many difficulties that decrease product quality (DeDiemar 1990; Svensson and Steer 1990). Herein, the rock-crusher interactions are also essential for evaluating the performance of crushers. For instance, by comparison with jaw and gyratory crushers, impact crushers can achieve a higher production yield. However, their use is limited due to high wear rates and is thus restricted to medium or weak rocks (Duthoit, 2000).

Comparing impact crushers, Nikolov (2004) proposed a dynamic particle model indicating that the impact of energy per unit mass in VSI-type crusher is greater than those of HSI-type crusher. Rahimdel and Ataei (2014) employed an analytical hierarchy process (AHP) to select primary crushing equipment. The AHP analyses indicated that the gyratory type of crusher could be a suitable option for the primary crushing operations of an iron mine in Iran. In another study, it was statistically found that the capacity of HSI-type crushers is lower than the one of cone crushers, leading to remarkable differences in their specific crushing energy consumptions. Nevertheless, this difference reduces with increasing the Los Angeles abrasion value (LAA) of rocks (Köken and Jili 2020). Therefore, rock crusher selection should be conducted rigorously because of the main differences in the specific crushing energy consumption.

In recent years, the performance of crushers has been investigated using discrete element methods (Li et al., 2014; Grunditz 2015; Quist and Evertsson 2016; Chen et al., 2020). When it comes to product-based evaluations, it has been acknowledged that rock crushing efficiency is associated with the configuration of process equipment, operational features, and rock properties of feed material. Tavares and Da Silveria (2008) reported that cone crusher capacity increases with decreasing the LAA of rocks. Lee and Evertsson (2011) stated that the setup of the cone crushing process affects the particle size distribution of the product. Moreover, the adjustment in broader strokes in cone crusher relatively enhances the production yield for specific size fractions. Therefore, interparticle compression in the crushing chamber should be emphasized to optimize production yield (Lee 2012). In addition, the feed gradation, variations in closed-side setting (CSS), and crusher speed affect the production yield, specific energy consumption, and product shape properties (Fladvad and Onnela 2020).

Focusing on product shape considerations, Kojovic (1995) pointed out the importance of choke feeding that improves the product shape. However, the choke feeding also causes fine material production due to extreme inter-particle compression (Guimaraes et al., 2007). Eloranta (1995) declared the feed gradation and stroke of crushers as dominating factors affecting the degree of crushability in cone crushing. 
Briggs and Evertsson (1998) stated that the shape properties of rock materials could be estimated through crushability tests, including varying operational features. Bengtsson and Evertsson (2006) found that industrial VSI type crushers provide better shape properties than cone crushers. Later on, based on VSI type crushers, a predictive model to estimate product size and shape properties was developed by Bengtsson (2009). Just as importantly, the impacts of rock breakage mechanisms on product angularity decrease in parallel with size reduction (Rajan and Singh 2017). It was reported by Hafeez et al. (2016) that rock aggregates produced through jaw and cone crushing circuits have a better cubical form when compared to those produced from the jaw crusher alone. Kamani and Ajalloeian (2020) stated that HSItype crushers provide better shape properties than jaw crushers. Consequently, it can be claimed that the aggregate morphology is highly dependent upon the crusher type and crushing circuit (Rajan and Singh, 2020).

For the rock strength considerations, the uniaxial compressive strength of rocks (UCS, MPa) is an essential parameter for quantifying rock crushability in jaw crushing (Korman et al., 2015; Kahraman et al., 2018; Köken and Özarslan 2018). On the other hand, the Brazilian tensile strength of rocks (BTS, MPa) can be a correlative parameter evaluating the crushing energy consumption in cone crushing (Köken 2020).

The studies mentioned above have provided adequate knowledge on rock crushability from different perspectives. In this study, rock aggregate production processes of a crushing - screening plant in northwestern Turkey were considered. The dynamic simulation of the crushing - screening plant was performed considering its current operating conditions. For different size fractions of products, some aggregate properties were determined in laboratory studies. Moreover, the variations in rock aggregate quality arising from several crushing circuits were presented as a case study. As a result of full-scale crushing tests, the quality of railway ballast aggregates was improved by several changes in the crushing circuit. The details and key points on these changes were explained within the context of the present study.

\section{MATERIALS AND METHODS}

\subsection{Introducing the crushing - screening plant}

The crushing - screening plant considered in this study is located in Vize, Kırklareli, Turkey. The plant produces filling material, concrete, subbase, and railway ballast aggregates. Employing drilling and blasting methods, rock blocks with different dimensions are obtained for crushing operations (Fig 1a). The aggregates are produced from granitic rocks composed of granite, metagranite, and granodiorite. The host rock has phaneritic and porphyritic textures and exhibits surface oxidation zones (Fig 1b). The rock masses are observed in the field studies as yellowish-brown in color and highly fractured in texture. Based on the field observations, the rock masses could be declared from slightly to moderately weathered, according to ISRM (2007). The blasted rock blocks are transported to the crushing - screening plant by trucks for aggregate production. The flow chart of the crushing - screening plant is given in Fig 2. In typical crushing - screening operations, rock blocks are initially scalped using a $70 \mathrm{~mm}$ grizzly feeder before first crushing. Then, rock materials above $70 \mathrm{~mm}$ are broken down by a jaw crusher whose dimensions are $1300 \mathrm{~mm} x$ $2400 \mathrm{~mm}$. The CSS of the jaw crusher is $140 \mathrm{~mm}$.

The crushed particles obtained from the jaw crusher are fed to the cone crusher. The CSS and throw of the cone crusher are 40 and $25 \mathrm{~mm}$, respectively. Crushed materials above $63 \mathrm{~mm}$ are returned to the cone crusher, and particles between $+5-63 \mathrm{~mm}$ are directed to the VSI. Simultaneously, some of the scalped materials $(+20-38 \mathrm{~mm})$ and those with $+22-33 \mathrm{~mm}$ are also fed and returned to the VSI, respectively (Fig 2).

Finally, crushed materials are sieved, and the products are obtained with different size fractions. Wet screening is adopted using water jet nozzles in the crushing - screening plant. Some scenes of the plant are given in Fig 3. 

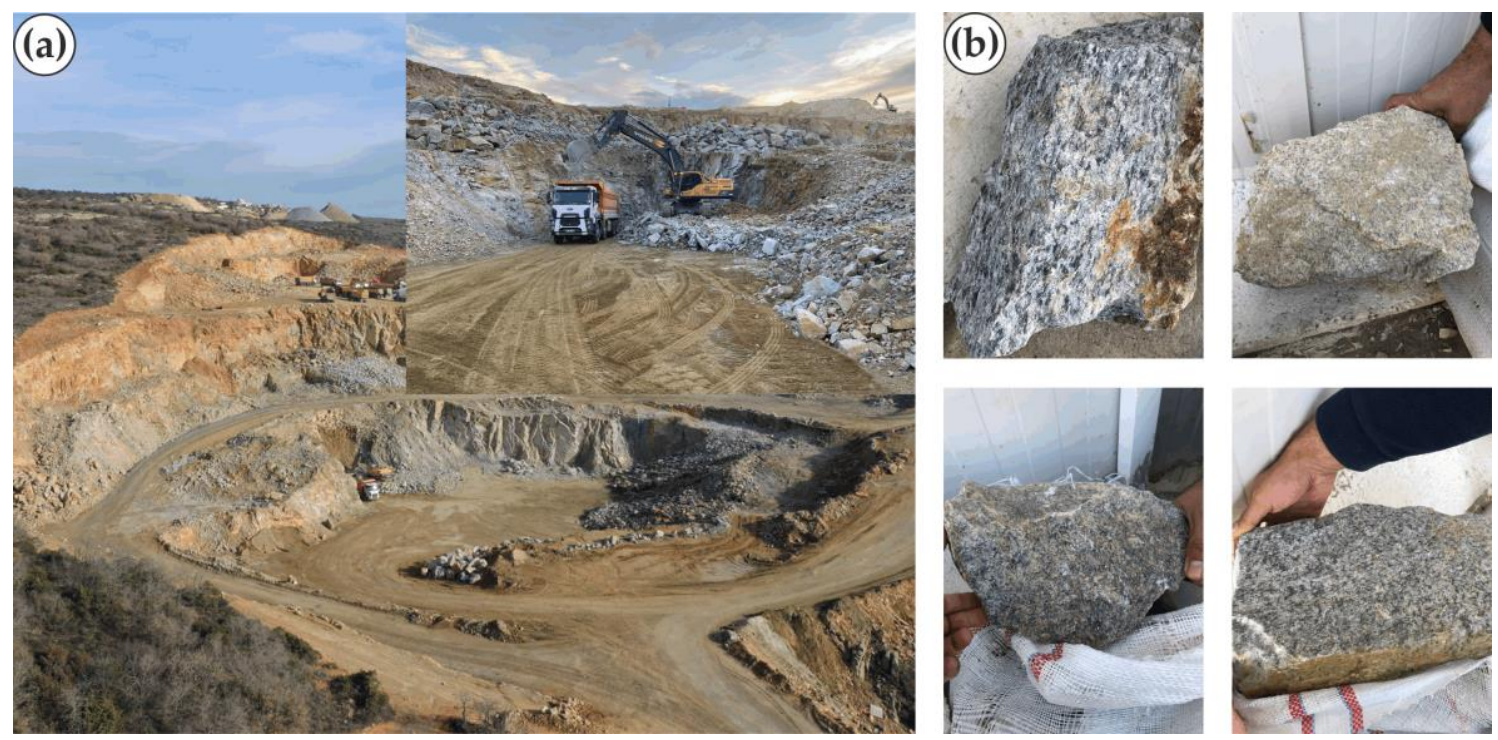

Figure 1. a) Overview of the study area b) Some of the host rocks processed in the crushing - screening plant

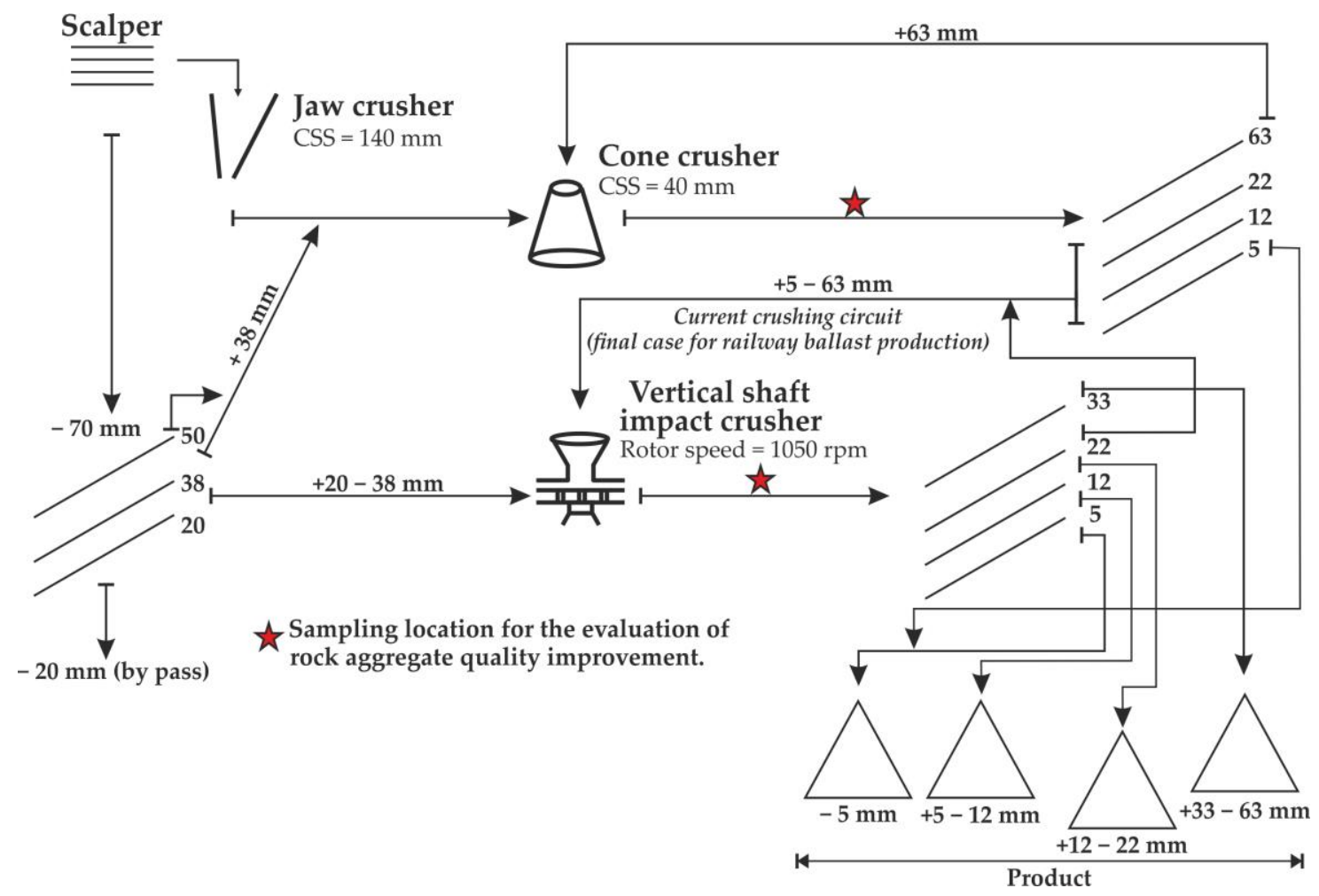

Figure 2. Flow chart of the crushing - screening plant. 

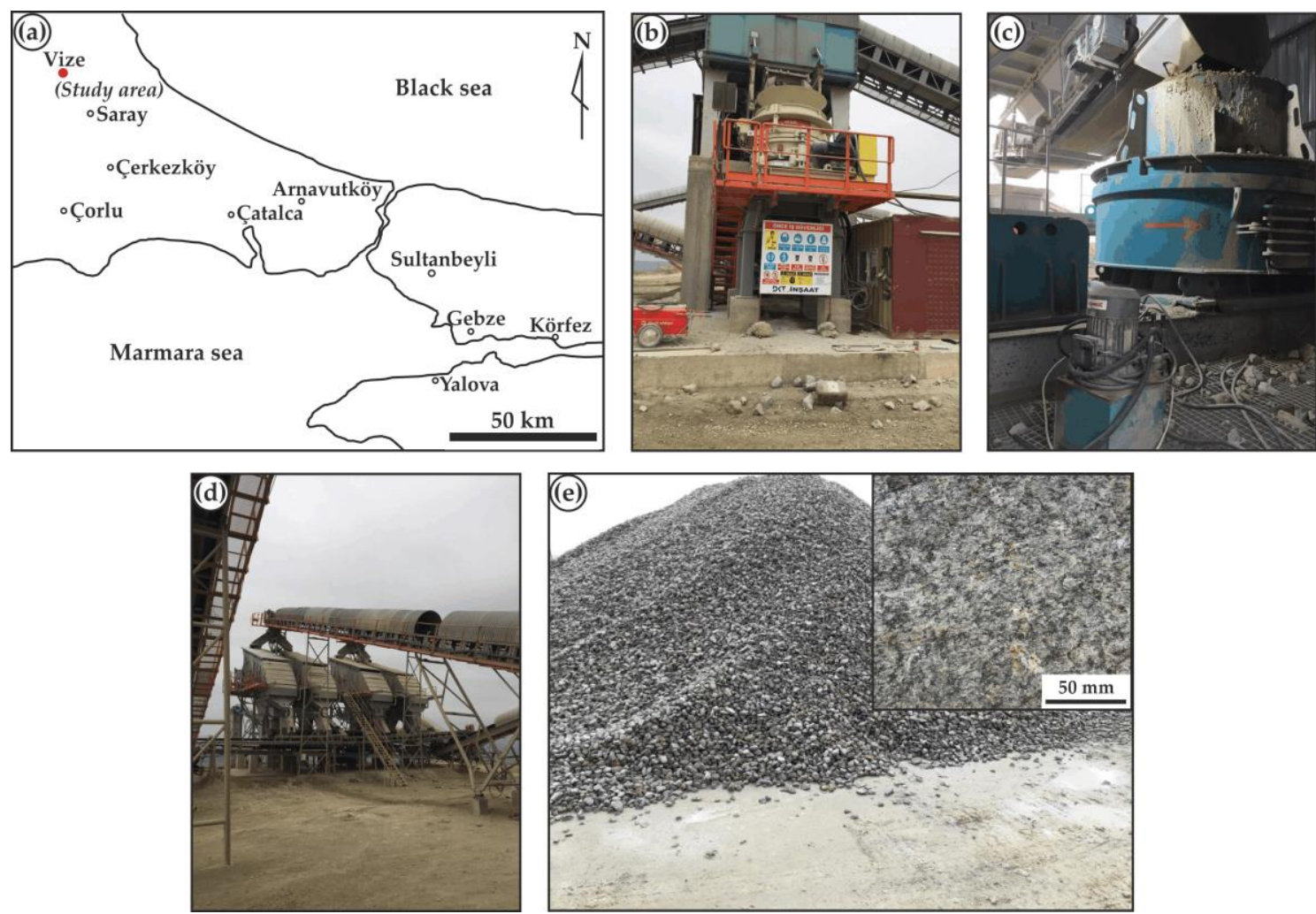

Figure 3. Some scenes of the crushing screening plant considered in this study a) Location map of the plant b) Cone crusher c) Vertical shaft impact crusher d) Screens e) Railway ballast aggregates

\subsection{Laboratory studies}

Rock aggregate properties considered in the laboratory studies were water absorption ( $\left.\mathrm{w}_{\mathrm{a}}, \%\right)$, LAA, and flakiness index (FI, \%). These aggregate properties were determined using products with particle size ranges of $5-12,12-22$, and $33-63 \mathrm{~mm}$. The wa was determined in accordance with BS EN 1097-6 (2013). The LAA and FI tests were also carried out following BS EN 1097-2 (2010) and BS EN 933-3 (2012), respectively.

The laboratory tests were performed under oven-dried conditions, and each test to determine the $\mathrm{w}_{\mathrm{a}}$, LAAV, and FI of products was performed five times for each size fraction. The average values obtained from the laboratory tests were presented as rock aggregate properties in this study. In addition, the measurements on aggregate gradation (i.e., coefficient of uniformity, $\mathrm{Cu}=\mathrm{d}_{60} / \mathrm{d}_{10}$ ) were also performed through sieve analyses, according to ASTM C136 / C136M (2019)

\section{RESULTS AND DISCUSSION}

\subsection{Simulation of the crushing - screening plant}

The crusher-screening plant was simulated using the software Bruno (v4.1.0.0). Based on the crusherscreening plant's current operating conditions, the simulations were carried out. The simulation results are presented as a flowchart in Fig 4.

Accordingly, the efficiency of the jaw, cone, and VSI-type crushers was found to be $59 \%, 86 \%$, and $77 \%$, respectively. For a typical crushing - screening shift, $200-300$ tons of feeding materials were processed in the plant. In this regard, rock aggregates with four different size fractions were obtained. Production yields for $-5,5-12,12-22$, and $33-63 \mathrm{~mm}$ ranged from $14 \%$ to $34 \%$. The waste material (bypass) passing through the scalp was about $7 \%$ of the total feed (Fig 4 ). 
The size reduction ratio (SRR) for the jaw, cone, and VSI-type crushers were about 6.1, 2.8, and 1.3, respectively (Table 1$)$. It should be noted that a significant part (23\% of the total feed) of products was obtained below $5 \mathrm{~mm}$ due to crushing actions held by the closed rotor of the VSI, which is typical for industrial VSI-type crushers in Turkey. Significant quantities of fine products produced from VSI type crushers were also reported by Lindqvist (2008).

Table 1. Simulation results.

\begin{tabular}{lcccc}
\hline $\begin{array}{c}\text { Crusher } \\
\text { type }\end{array}$ & $\begin{array}{c}\text { Size reduction ratio, } \\
\text { SRR }\end{array}$ & $\begin{array}{c}\text { Efficiency } \\
(\%)\end{array}$ & $\begin{array}{c}\text { Product } \\
\text { size }(\mathrm{mm})\end{array}$ & $\begin{array}{c}\text { Production } \\
\text { yield }(\%)\end{array}$ \\
\hline Jaw & 6.1 & 59 & $0-5$ & 23 \\
Cone & 2.8 & 86 & $5-12$ & 22 \\
VSI & 1.3 & 77 & $12-22$ & 14 \\
& & & $33-63$ & 34 \\
\hline
\end{tabular}

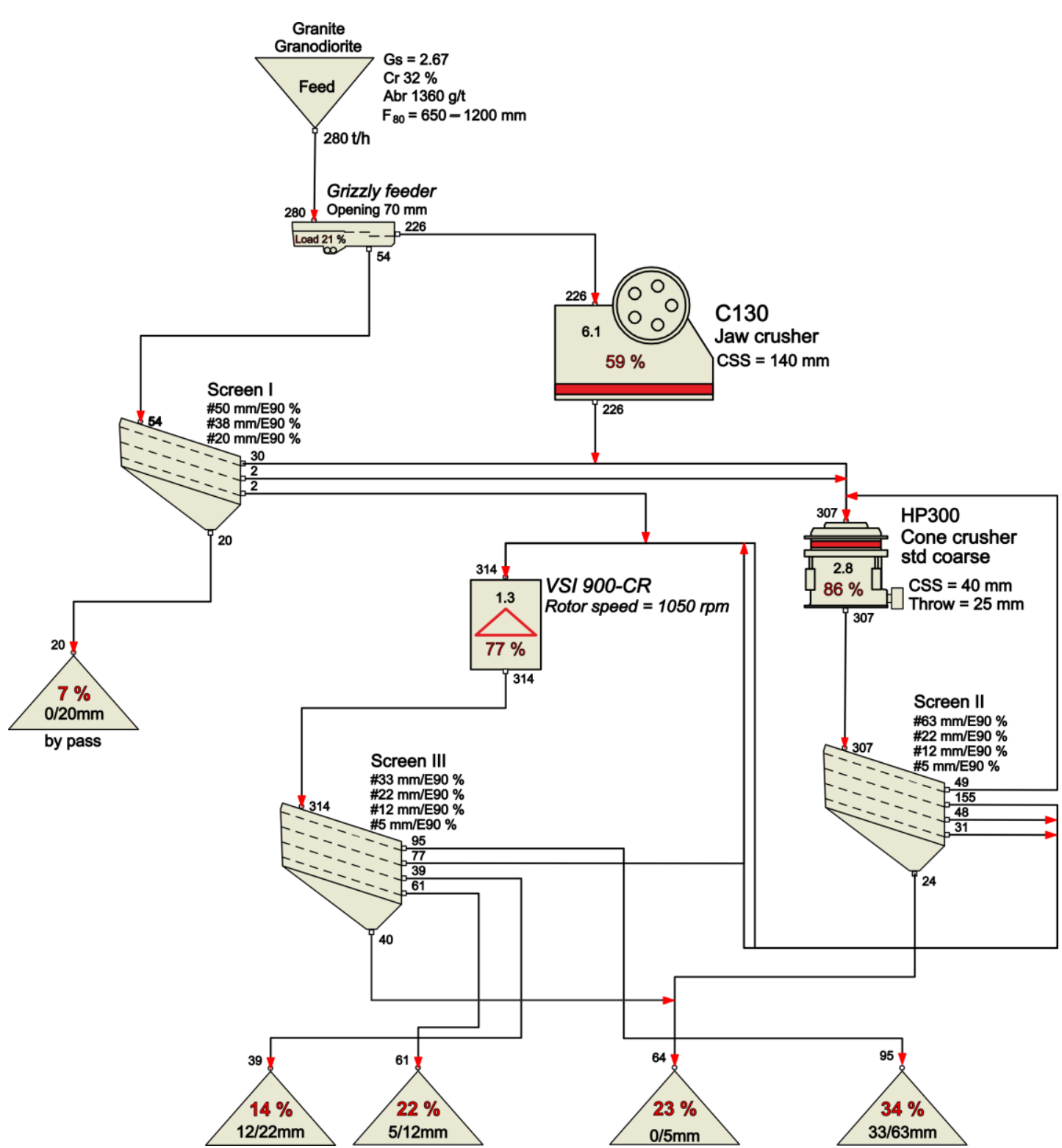

Figure 4. Simulation of the crushing - screening plant investigated in this study. 


\subsection{Aggregate properties of products}

Based on different size fractions, aggregate properties determined in this study are given in Fig 5 . The coefficient of uniformity $\left(\mathrm{c}_{u}=\mathrm{d}_{60} / \mathrm{d}_{10}\right)$ of products varied from 1.47 to 1.50 (Fig $\left.5 \mathrm{a}\right)$ ), showing the relative homogeneity of products. Such cu values were also obtained by Ajamu and İge (2015) and Nduka et al. (2018). Before using these products for construction purposes, rock aggregates with different size fractions should be appropriately mixed to increase the $\mathrm{cu}$ and, therefore, the packing density of concrete structures (Nanthagopalan and Santhanam 2012). Besides, aggregate gradation also influences the mechanical properties of aggregates, which is also essential in railway ballast layers (Xiao et al., 2012).

The LAA of products decreased with increasing its size. It was found to be between $15 \%-25 \%$ (Fig $5 b$ ). The wa was around $0.5 \%-0.6 \%$ (Fig $5 \mathrm{c}$ ). Finally, the FI varied from $6 \%$ to $13 \%$ (Fig $5 \mathrm{~d}$ ). Based on the findings in Fig 5, it can be claimed that the treatment of aggregate production (Fig 2) is suitable to achieve products with satisfactory quality. The obtained LAA values of the products are reasonable and meet ASTM D692/D692M (2015) requirements for bituminous paving mixtures.

(ai)

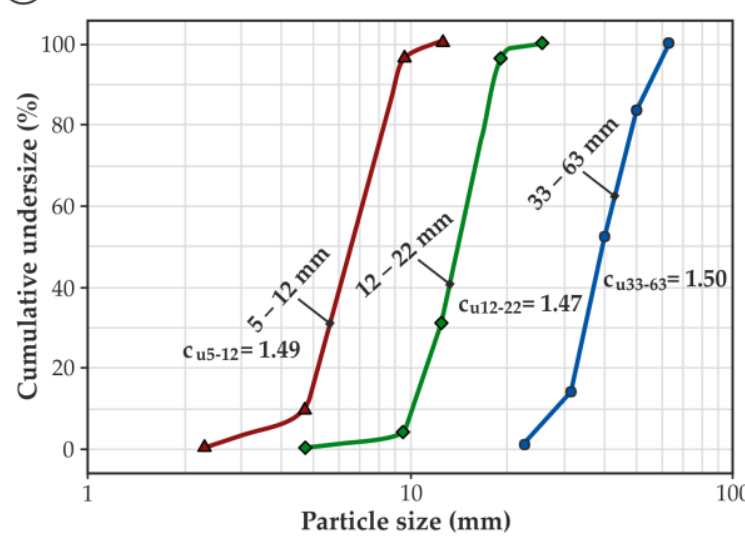

(bi)

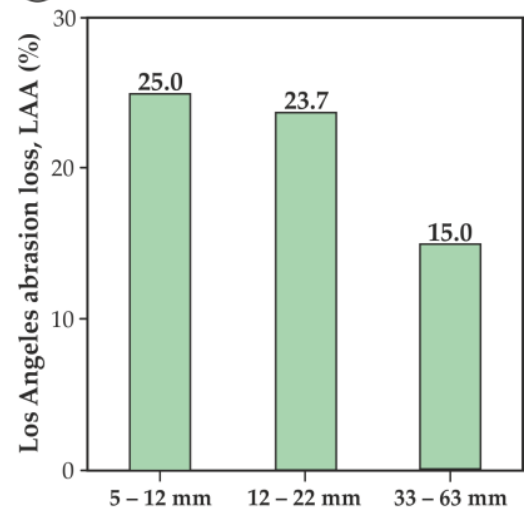

(c)

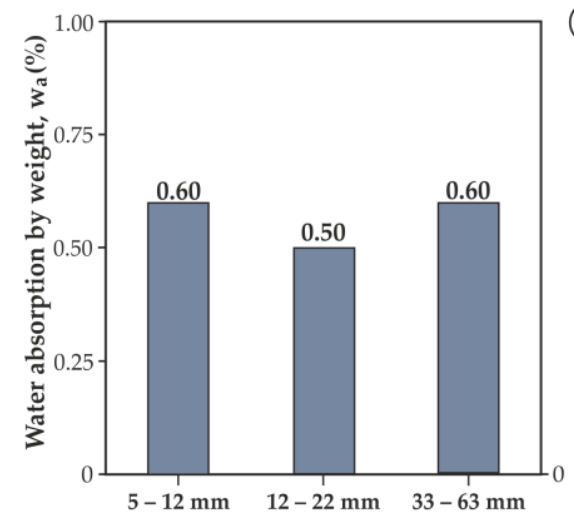

(di)

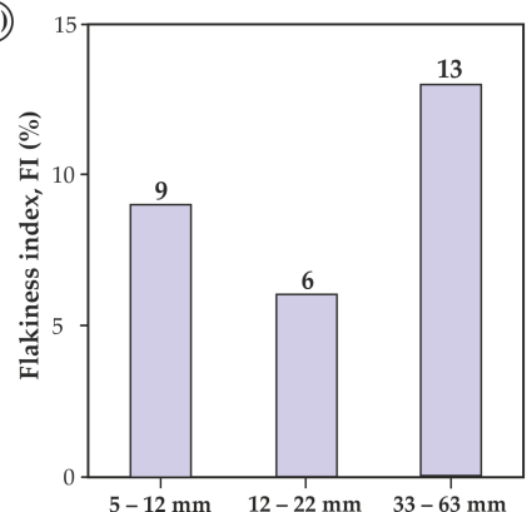

Figure 5. General features of the rock aggregates with different size fractions a) Particle size distribution b) LAA test results c) wa test results d) FI test results

\subsection{Applications on the improvement of rock aggregate quality}

The quality of rock aggregates with a particle size range of $33-63 \mathrm{~mm}$ was investigated by focusing on the crushing circuit changes. Several crushing circuits were attempted, and one feasible procedure was presented in this study. In the early stages of the crushing circuit, the crushed materials processed from the cone crusher were sieved, and ballast aggregates with a particle size range of $+33-63 \mathrm{~mm}$ were obtained (Fig 6a). However, the FI and LAA of those were not within the limits of railway ballast specifications of Turkey (TS 7043 EN 13450, 2004). 
The cone crusher products were then separated and gradually directed to the VSI based on different feed sizes. Systematic sampling was performed for laboratory testing in each case, where the LAA and FI values were determined. As a result of crushing circuit changes, the most feasible method for ballast aggregate production was based on the condition that crushed stones $(+5-63 \mathrm{~mm})$ obtained from the cone crusher were directed to the VSI (Fig 6b).
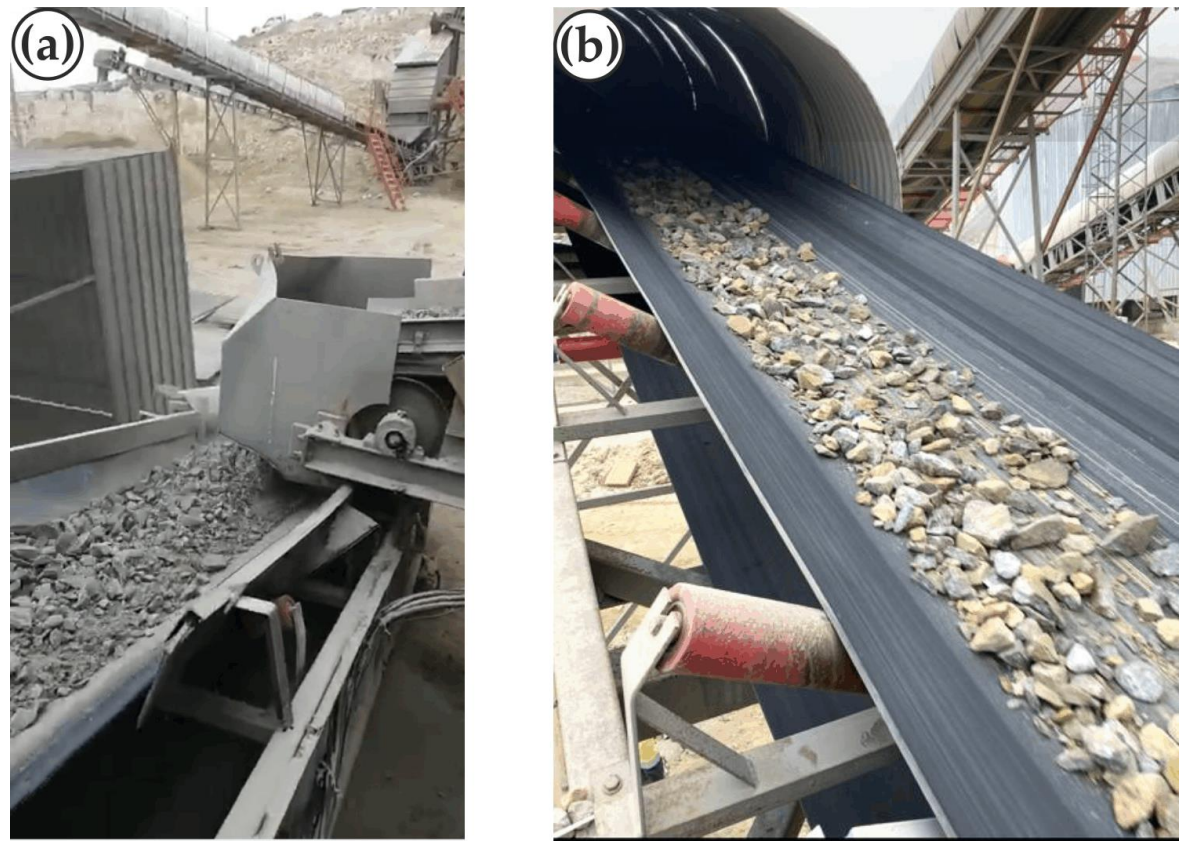

Figure 6. Illustration of crushing circuit change a) Products obtained from the cone crusher (initial stage) b) crushed stones fed to the VSI (final case).

It was observed that the LAA enhanced thanks to the direction of selective products $(+5-63 \mathrm{~mm})$ to the VSI, given as in Fig 2. Before changing the crushing circuit, the LAA for the specified size fraction was around $22 \%$. After the explained procedure, the LAA was found to be around $15 \%$, enhancing the ballast aggregate quality by $32 \%$. The verification of this improvement was also cross-checked through the FI tests. Before and after the procedure, the FI of aggregates was around $20 \%$ and $13 \%$, respectively. The improvement ratio in shape was $35 \%$ (Table 2).

Table 2. LAA values of ballast aggregates

\begin{tabular}{llll}
\hline $\begin{array}{l}\text { Rock aggregates produced } \\
\text { from the cone crusher } \\
(31.5-50.0 \mathrm{~mm})\end{array}$ & \multicolumn{2}{l}{$\begin{array}{l}\text { Rock aggregates produced from the } \\
\text { vertical shaft impact crusher } \\
(31.5-50.0 \mathrm{~mm})\end{array}$} \\
\hline LAA $(\%)$ & Test date & LAA $(\%)$ & Test date \\
25.4 & 18.10 .2020 & 14.1 & 21.12 .2020 \\
21.1 & 20.10 .2020 & 15.5 & 22.12 .2020 \\
18.6 & 23.10 .2020 & 13.6 & 25.12 .2020 \\
& & 16.8 & Test date \\
\hline FI (\%) & Test date & FI (\%) & \\
\hline 22.0 & & 12.3 & 22.12 .2020 \\
18.1 & 18.10 .2020 & 15.6 & \\
18.4 & & 11.0 & 25.12 .2020 \\
21.4 & 20.10 .2020 & 14.5 & \\
\hline
\end{tabular}


The improvement in product shape is in good agreement with the findings of Bengtsson and Evertsson (2006). It is also worth mentioning that the process of dynamic fragmentation for impact crushers exploits the presence of micro-fissures or discontinuities in/on rock aggregates (Djordjevic et al., 2003). Hence the products obtained from impact crushers tend to be of good quality and present satisfactory shape properties. From this point of view, the combination of cone and VSI crushers can be declared a feasible choice for railway ballast aggregate production.

As a concluding remark, during the change in the crushing circuit, the rotor speed of the VSI was reduced to primarily prevent damages to linings, decrease fine material production, and provide optimal LAA for ballast aggregates. In this study, the pulley propelling the main shaft of the rotor was altered with the one with a lower diameter $(26 \mathrm{~cm})$. Under this condition, the rotor speed was around $1050-1075 \mathrm{rpm}$. With this modification, the rotor speed was reduced by $27 \%$, improving the product quality. Last but not least, it should be reminded that in this study, selective drilling-blasting methods were not considered for the evaluation of rock aggregate quality. However, it can be beneficial to consider it in further studies. In this way, the feasibility of selective drilling-blasting should be revealed whether it would be either technically or financially reasonable. The rock aggregate quality improvement or optimization of aggregate production should also be investigated through soft computing tools, increasing the number of independent variables during crushing circuits.

\section{CONCLUSIONS}

Rock aggregate production is hard work that requires high-quality equipment, sensibility, and work experience. Several attempts have been made to diminish operating costs and enhance product quality from different points of view regarding crushing- screening plants. In this study, a crushing - screening plant in Vize, Kırklareli - Turkey, was considered to investigate rock aggregate quality due to several crushing circuits.

The flow chart of the plant was established and simulated concerning the operating features (Fig 4). Some of the aggregate properties were determined for specific size fractions (Fig 5). Several crushing circuits were attempted to observe the possible changes in ballast aggregate quality. As a result of fullscale crushing tests, it was observed that a notable improvement in ballast aggregate quality is reached by changing the crushing circuit.

Using a VSI-type crusher, the railway ballast aggregate quality was improved in terms of their abrasion resistance and shape properties (Table 2). Therefore, it can be claimed that the modifications in crushing circuits may be a reasonable way to improve rock aggregate quality. In this way, natural resources could be used effectively in the building and construction sectors. Before crushing operations, selective drilling-blasting methods should also be attempted in the field studies. It is clear that with selective drilling-blasting, the initial cost of rock aggregates increases so thus the aggregate quality. The feasibility of this hypothesis should be investigated in future works.

\section{Compliance with ethical standards}

The authors declare that they have no known competing financial interests or personal relationships that could have influenced the work reported in this paper.

\section{REFERENCES}

Ajamu, S.O. and Ige, J.A., 2015, "Influence of coarse aggregate types and mixing method of concrete made from natural aggregate", International Journal of Engineering and Technology, 5(7), 2049 - 3444.

ASTM C136 / C136M ,2019, "Standard Test Method for Sieve Analysis of Fine and Coarse Aggregates", ASTM International

ASTM D692/692M ,2015, “Standard specification for coarse aggregate for bituminous paving mixtures. ", ASTM International 
Bengtsson M. and Evertsson C.M., 2006, "Measuring characteristics of aggregate material from vertical shaft impact crushers", Minerals Engineering. 19(15), 1479 - 1486.

Bengtsson, M., 2009, "Quality-driven production of aggregates in crushing plants", Dissertation, Chalmers University of Technology.

Briggs, C., \& Evertsson, C. M.., 1998, “Shape potential of rock.", Minerals Engineering, 11(2), 125-132.

BS EN 933-3, 2012, “Tests for geometrical properties of aggregates: Determination of particle shape, Flakiness index", British Standards Institution, London

BS EN 1097-2, 2010, “Tests for mechanical and physical properties of aggregates: methods for the determination of resistance to fragmentation. ", British Standards Institution, London

BS EN 1097-6, 2013, “Tests for mechanical and physical properties of aggregates: determination of particle density and water absorption. "British Standards Institution, London

Chen Z. Wang G. Xue D. and Bi Q., 2020, "Simulation and optimization of gyratory crusher performance based on the discrete element method", Powder Technology, 376, 93 - 103.

Davoodi A., Asbjörnsson G., Hulthén E. and Evertsson M., 2019, “Application of the discrete element method to study the effects of stream characteristics on screening performance", Minerals, 9(12): 788 .

DeDiemar R., 1990, "New concepts in jaw crusher technology", Minerals Engineering, 3(1-2), 67 - 74.

Djordjevic N., Shi F.N. and Morrison R.D., 2003, “Applying discrete element modelling to vertical and horizontal shaft impact crushers", Minerals Engineering, 16(10), 983 - 991.

Duthoit, V., 2000, "Crushing and grinding aggregates", Chapter. 9, (Ed. Louis Primel and Claud Tourenq). Balkema, Rotterdam

Eloranta, J., 1995, "Influence of crushing process variables on the product quality of crushed rock. ", Dissertation, Tampere University of Technology.

Fladvad M. and Onnela T., 2020, "Influence of jaw crusher parameters on the quality of primary crushed aggregates", Minerals Engineering. 151: 106338.

Guimaraes, M. S., Valdes, J. R., Palomino, A. M., \& Santamarina, J.C., 2007, “Aggregate production, fines generation during rock crushing", International Journal Mineral Processing, 81(4), 237-247.

Grunditz S., 2015, "Modeling and optimization of a vertical shaft impactor for production of artificial sand", Master Thesis, Chalmers University of Technology

Hafeez I., Juniad F., Kamal M.A. and Hussain J., 2016, “Influence of single- and two-stage aggregate manufacturing mechanisms on asphalt mixture performance", Journal Materials in Civil Engineering 28(4), 04015180

ISRM., 2007, "The complete ISRM suggested methods for rock characterization, testing, and monitoring", 1974-2006. In: R. Ulusay, \& J. A. Hudson (Eds.), Suggested methods prepared by the commission on testing methods. International Society of Rock Mechanics (ISRM), Ankara, Turkey.

Kahraman S., Toraman O.Y., and Cayirli S., 2018, "Predicting the strength and brittleness of rocks from a crushability index", Bulletin of Engineering Geology and the Environment, 77(4), 1639 - 1645.

Kamani M. and Ajalloeian R., 2020, "The effect of rock crusher and rock type on the aggregate shape", Construction and Building Materials, 230, 117016

Kojovic, T., 1995, “Crushers: A quarry Australia special feature”, Quarry, 26-34.

Korman, T., Bedekovic, G., Kujundzic, T., \& Kuhinek, D., 2015, “Impact of physical and mechanical properties of rocks on energy consumption of jaw crusher", Physicochemical Problems of Mineral Processing, 51(2): $461-475$.

Köken, E., and Özarslan, A., 2018, “New testing methodology for the quantification of rock crushability, compressive crushing value (CCV).", International Journal of Mineral Metallurgy and Materials, 25(11), 1227-1236

Köken E., 2020, "Evaluation of size reduction process for rock aggregates in cone crusher", Bulletin of Engineering Geology and the Environment, 79, 4933 - 4946

Köken E., Top S. and Özarslan A., 2020, “Assessment of rock aggregate quality through the analytic hierarchy process (AHP)", Geotechnical and Geological Engineering 38, 5075 - 5096, 
Köken E. and Jili Q., 2020, “Comparison of secondary crushing operations through cone and horizontal shaft impact crushers", In: 20th International Multidisciplinary Scientific Geoconference, SGEM 2020, pp $789-796$

Lee E, Evertsson C.M., 2011, "A comparative study between cone crushers and theoretically optimal crushing sequences", Minerals. Engineering 24:188-194.

Lee E., 2012, "Optimization of compressive crushing", Dissertation, Chalmers University of Technology, Göteborg.

Leiva, C. A., Arcos, K. V., Poblete, D. A., Serey, E. A., Torres, C. M., \& Ghorbani, Y., 2018, “Design and evaluation of an expert system in a crushing plant." Minerals, 8(10), 469.

Li H. McDowell G.R. and Lowndes I.S., 2014, Discrete element modelling of a rock cone crusher", Powder Technology 63, $151-158$.

Lindqvist M., 2008, "Energy considerations in compressive and impact crushing of rock", Minerals Engineering, 21(9), 631 - 641.

Metso., 2018, “Basics in mineral processing handbook.", Metso Corporation.

Nanthagopalan, P. and Santhanam, M., 2012, "An empirical approach for the optimisation of aggregate combinations for self-compacting concrete.", Materials and Structures, 45, 1167 - 1179.

Nduka D.O., Fabgenle O.I. Joshua O., Ogunde A.O. and Omuh I.O., 2018, "Comparative analysis of concrete strength utilizing quarry-crushed and locally sourced coarse aggregates", International Journal of Mechanical Engineering Technology, IJMET, 9(1), 609 - 617

Nikolov, S., 2004, "Modelling and simulation of particle breakage in impact crushers.", International Journal of Mineral Processing, 74(10): 219-225.

Quist J. and Evertsson C.M., 2016, "Cone crusher modelling and simulation using DEM", Minerals Engineering, 85: 92 - 105.

Rahimdel M.J. and Ataei M., 2014, "Application of analytical hierarchy process to selection of primary crusher", International Journal of Mining Science and Technology, 24: 519 - 523.

Rajan B. and Singh D., 2017, "Understanding influence of crushers on shape characteristics of fine aggregates based on digital image and conventional techniques", Construction and Building Materials, 150: 833 - 843.

Rajan B. and Singh D., 2020, "Investigation on effects of different crushing stages on morphology of coarse and fine aggregates", International Journal of Pavement Engineering 21(2), 177 -195.

Svensson, A.; Steer, J.F., 1990, “New cone crusher technology and developments in comminution circuits.", Minerals Engineering, 3, 83-103.

Tavares L.M. and Da Silveria M.A.C.W., 2008, "Comparison of measures of rock crushability", In Fine Particle Technology and Characterization, (Meftuni Yekeler Eds), ISBN: 978-81-308-0241-1

TS 7043 EN 13450, 2004, "Aggregates for railway ballast", Turkish Standards Institution, Ankara

Ulsen, C., Tseng, E., Angulo, S. C., Landmann, M., Contessotto, R., Balbo, J. T., Kahn, H., 2019, “Concrete aggregate properties crushed by jaw and impact secondary crushing.", Journal of Materials Research and Technology,8(1), 494-502.

Xiao Y., Tutumluer E., Qian Y. and Siekmeier J.A., 2012, "Gradation effects influencing mechanical properties of aggregate base-granular subbase materials in Minnesota", Transportation Research Record, 2267(1): $14-26$ 